\title{
Mechanisms leading to hypogonadism in men with burns injuries
}

\author{
C G SEMPLE，W R ROBERTSON， R MITCHELL， D GORDON， C E GRAY， G H BEASTALL, \\ W H REID
}

\begin{abstract}
A profound and persistent depression of serum testosterone concentrations was found in 19 men with burns injuries. This could not be explained by changes in sex hormone binding globulin capacity, hyperprolactinaemia, classical primary testicular failure, or a hypogonadotrophic state. Pulsatile release of luteinising hormone was found in control subjects but was absent or diminished in burnt patients with low serum testosterone concentrations. In addition, these patients showed reduced biological activity of luteinising hormone as measured by bioassay even though normal concentrations of luteinising hormone were detected by radioimmunoassay.

The temporary hypogonadism after burns injury and possibly in other clinical states may be related to hypothalamic dysfunction, which leads to abnormal generation of luteinising hormone releasing hormone and non-pulsatile secretion of luteinising hormone of reduced biological activity.
\end{abstract}

\section{Introduction}

Hypogonadism is a recognised feature of chronic renal failure and chronic liver disease. ${ }^{12} \mathrm{~A}$ low serum testosterone concentration has also been described in men after burns injury, ${ }^{3.5}$ respiratory failure, ${ }^{6}$ surgery, ${ }^{7}$ myocardial infarction, ${ }^{8}$ and head injury. ${ }^{9}$ Gonadotrophin concentrations in postmenopausal women seem to fall with illness, ${ }^{10}$ as do those in men after head injury. ${ }^{91}$ Men with low testosterone

Medical Unit B, Southern General Hospital, Glasgow

C G SEMPLE, MRCP, senior medical registrar

Department of Chemical Pathology, Hope Hospital, Salford

W R ROBERTSON, PHD, senior research fellow

R MITCHELL, research technician

Glasgow Royal Infirmary, Glasgow

D GORDON, MRCP, medical registrar, university department of medicine CE GRAY, PHD, principal biochemist, department of biochemistry G H BEASTALL, PHD, top grade biochemist, department of biochemistry W H REID, FRCS, consultant surgeon, burns unit

Correspondence to: Dr Semple. concentrations from other causes usually have normal gonadotrophin concentrations. ${ }^{11}$

Burnt patients with low serum testosterone concentrations usually have luteinising hormone concentrations similar to those in healthy subjects matched for age, although concentrations of follicle stimulating hormone may be depressed..$^{3.5}$ Thus these low serum testosterone concentrations cannot be explained by primary testicular failure. On the other hand, concentrations of luteinising hormone are not reduced to the extent that would be expected if hypothalmic-pituitary suppression was the main aetiological factor. Burnt patients are a suitable model for studying the association between low testosterone concentrations and normal gonadotrophin concentrations in illness because this abnormality is often profound and may persist for several weeks.

In normal men secretion of luteinising hormone is usually pulsatile $^{12}$ and the circulating luteinising hormone is of variable biological potency. ${ }^{13}$ Consequently, a failure to release luteinising hormone of a normal biological activity and in the normal pulsatile pattern might contribute to the hypogonadism found in burnt men. We examined this hypothesis.

\section{Methods}

We studied 19 men (aged 20-69, mean 37; burnt surface area 4-70\%, mean $20 \%$ ) who had been admitted to a regional burns unit. We obtained permission from the ethical committee for the study and informed consent from those patients who underwent dynamic investigations. Blood samples were taken between 0800 and 1000 from 19 controls matched for age and from the burnt patients at the same time of day during routine venesection within 24 hours after admission (week 1) and thereafter at weekly intervals for four weeks (weeks 2-5). Not every patient was studied on each occasion owing to death (two patients), early discharge, poor venous access, and an inadequate volume of serum. Six of the 19 patients received parenteral opiates within 48 hours after admission but not thereafter. When necessary a paracetamol and codeine mixture containing only $16 \mathrm{mg}$ codeine in each dose was given as an analgesic.

During the second week after burns injury seven patients underwent studies to assess the pulsatility of luteinising hormone: six had low testosterone concentrations and one a normal concentration, although this had reached a nadir of $4.5 \mathrm{nmol} / 1$ during the previous week. At 0900 an indwelling venous cannula was inserted into the antecubital fossa and kept patent with $0.5 \mathrm{ml}$ heparin solution $(10 \mathrm{U} / \mathrm{ml})$ between sampling times. Blood ( $5 \mathrm{ml}$ ) was withdrawn every 15 minutes for six hours and clotted. To assess the ability of the pituitary to secrete luteinising hormone $100 \mu \mathrm{g}$ 
gonadorelin (luteinising hormone releasing hormone) was then injected intravenously into six of the patients and further samples of blood taken and clotted 30 and 60 minutes later. The ability of the testes to secrete testosterone was assessed by a human chorionic gonadotrophin stimulation test; human chorionic gonadotrophin (2000 units) was injected intramuscularly after completion of the luteinising hormone releasing hormone test (day 1) and two days later (day 3) with repeat blood samples being obtained at 0900 on day 5 .
Sex hormone binding globulin capacity was measured by a modification of the method of Rosner. ${ }^{15}$ Free testosterone was derived from the formula: $\%$ free testosterone $=2 \cdot 28-1.38 \log _{10}$ (sex hormone binding globulin capacity). ${ }^{16}$ Analysis of pulses of luteinising hormone was by a modification of the method of Santen and Bardin. ${ }^{17}$ A pulse was considered to be present if two consecutive values of luteinising hormone were more than $20 \%$ higher than the preceding nadir. The area under the curve was determined by adding each value of luteinising hormone obtained in the six

TABLE I-Mean (SE) concentrations of hormones and sex hormone building globulin capacity in burnt men after admission (week 1 ) and for four weeks thereafter compared with values in control men matched for age

\begin{tabular}{|c|c|c|c|c|c|c|}
\hline & \multirow{2}{*}{$\begin{array}{c}\text { Controls } \\
(n=19)\end{array}$} & \multicolumn{5}{|c|}{ Patients } \\
\hline & & Week 1 & Week 2 & Week 3 & Week 4 & Week 5 \\
\hline Testosterone (nmol/l) & $18.9(1.4)$ & $\begin{array}{l}6 \cdot 8(1 \cdot 8)^{\star \star \star} \\
(n=19)\end{array}$ & $\begin{array}{l}4 \cdot 4(1 \cdot 7)^{\star \star \star} \\
(n=11)\end{array}$ & $\begin{array}{l}4 \cdot 1(1 \cdot 4)^{\star \star \star} \\
(n=12)\end{array}$ & $\begin{array}{l}7 \cdot 3(2 \cdot 1)^{\star \star \star} \\
(n=10)\end{array}$ & $\begin{array}{l}7 \cdot 8(2 \cdot 3)^{\star \star \star} \\
(n=12)\end{array}$ \\
\hline Sex hormone building globulin $(\mathrm{nmol} / \mathrm{l})$ & $29 \cdot 9(1 \cdot 8)$ & $\begin{array}{c}21 \cdot 2(3 \cdot 2)^{\star \star} \\
(n=19)\end{array}$ & $\begin{array}{r}24 \cdot 7(3.5) \\
(n=12)\end{array}$ & $\begin{array}{c}33 \cdot 3(4 \cdot 0) \\
(n=12)\end{array}$ & $\begin{array}{c}38 \cdot 2(4 \cdot 1)^{\star \star} \\
(n=11)\end{array}$ & $\begin{array}{c}34 \cdot 1(3 \cdot 3) \\
(n=12)\end{array}$ \\
\hline Derived free testosterone $(\mathrm{pmol} / \mathrm{l})$ & $315(26)$ & $\begin{array}{c}117(29)^{\star \star \star \star} \\
(n=19)\end{array}$ & $\begin{array}{c}71(30)^{\star \star \star \star} \\
(n=12)\end{array}$ & $\begin{array}{c}67(24)^{\star \star \star \star} \\
(n=12)\end{array}$ & $\begin{array}{c}105(31)^{\star} \\
(n=11)\end{array}$ & $\begin{array}{c}133(51) \star \star \star \star \\
(n=12)\end{array}$ \\
\hline Follicle stimulating hormone (U/l) & $3 \cdot 2(0 \cdot 5)$ & $\begin{array}{c}2 \cdot 1(0 \cdot 4) \\
(n=19)\end{array}$ & $\begin{array}{l}1 \cdot 7(0.4)^{\star} \\
(n=12)\end{array}$ & $\begin{array}{c}2 \cdot 6(0 \cdot 4) \\
(n=12)\end{array}$ & $\begin{array}{c}1 \cdot 9(0 \cdot 4) \\
(n=10)\end{array}$ & $\begin{array}{c}4 \cdot 6(1 \cdot 1) \\
(n=10)\end{array}$ \\
\hline Luteinising hormone $(\mathrm{U} / \mathrm{l})$ & $4 \cdot 7(0 \cdot 4)$ & $\begin{array}{c}4 \cdot 3(0 \cdot 7) \\
(n=19)\end{array}$ & $\begin{array}{c}5 \cdot 5(1 \cdot 0) \\
(n=11)\end{array}$ & $\begin{array}{c}4 \cdot 6(1 \cdot 0) \\
(n=12)\end{array}$ & $\begin{array}{c}5 \cdot 8(0 \cdot 9) \\
(n=10)\end{array}$ & $\begin{array}{c}6 \cdot 2(1 \cdot 2) \\
(n=12)\end{array}$ \\
\hline Prolactin (mU/1) & $205(18)$ & $\begin{array}{l}248(58) \\
\quad(n=14)\end{array}$ & $\begin{array}{c}346(74) \\
\quad(n=9)\end{array}$ & $\begin{array}{l}366(76) \\
\quad(n=11)\end{array}$ & $\begin{array}{c}295(50) \\
\quad(n=9)\end{array}$ & $\begin{array}{l}275(56) \\
\quad(n=11)\end{array}$ \\
\hline
\end{tabular}

${ }^{\star} \mathrm{p}<0.05 .{ }^{\star \star} \mathrm{p}<0.02 .{ }^{\star \star \star} \mathrm{p}<0.001$.

TABLE II-Pulsatility of luteinising hormone in normal and burnt men

\begin{tabular}{|c|c|c|c|c|c|c|}
\hline \multirow{2}{*}{$\begin{array}{l}\text { Case } \\
\text { No }\end{array}$} & \multirow{2}{*}{$\begin{array}{c}\text { Testosterone } \\
(\mathrm{nmol} / \mathrm{l})\end{array}$} & \multirow{2}{*}{$\begin{array}{c}\text { Mean } \\
\text { luteinising hormone } \\
(\mathrm{U} / \mathrm{l})\end{array}$} & \multirow{2}{*}{$\begin{array}{c}\text { Area under } \\
\text { luteinising hormone } \\
\text { curve (U/I) }\end{array}$} & \multirow{2}{*}{$\begin{array}{c}\text { No of } \\
\text { pulses } / 6 \mathrm{~h}\end{array}$} & \multicolumn{2}{|c|}{ Mean amplitude of pulse } \\
\hline & & & & & $\%$ & $\mathrm{U} / 1$ \\
\hline \multicolumn{7}{|c|}{ Control subjects } \\
\hline $\begin{array}{l}1 \\
2 \\
3 \\
4 \\
5 \\
6\end{array}$ & $\begin{array}{l}11 \cdot 6 \\
14 \cdot 6 \\
37 \cdot 8 \\
30 \cdot 0 \\
33 \cdot 0 \\
19 \cdot 2\end{array}$ & $\begin{array}{l}4 \cdot 1 \\
3 \cdot 7 \\
4 \cdot 0 \\
6 \cdot 1 \\
3 \cdot 4 \\
4 \cdot 2\end{array}$ & $\begin{array}{r}103 \\
93 \\
100 \\
152 \\
84 \\
106\end{array}$ & $\begin{array}{l}3 \\
3 \\
3 \\
4 \\
3 \\
3\end{array}$ & $\begin{array}{l}51 \\
42 \\
72 \\
51 \\
85 \\
50\end{array}$ & $\begin{array}{l}1 \cdot 8 \\
1.3 \\
2 \cdot 7 \\
2 \cdot 6 \\
2.0 \\
1.6\end{array}$ \\
\hline Mean & $24 \cdot 4$ & $4 \cdot 3$ & 106 & $3 \cdot 2$ & 58 & $2 \cdot 0$ \\
\hline \multicolumn{7}{|c|}{ Burnt patients } \\
\hline $\begin{array}{r}7 \\
8 \\
9 \\
10 \\
11 \\
12\end{array}$ & $\begin{array}{l}2 \cdot 6 \\
2 \cdot 3 \\
1 \cdot 7 \\
8 \cdot 2 \\
4 \cdot 5 \\
1 \cdot 0\end{array}$ & $\begin{array}{l}4 \cdot 1 \\
5.8 \\
5.1 \\
5.5 \\
3 \cdot 8 \\
1.0\end{array}$ & $\begin{array}{r}102 \\
144 \\
128 \\
137 \\
96 \\
25\end{array}$ & $\begin{array}{l}0 \\
3 \\
2 \\
1 \\
1 \\
0\end{array}$ & $\begin{array}{r}39 \\
72 \\
58 \\
250\end{array}$ & $\begin{array}{l}1.9 \\
2 \cdot 7 \\
2.9 \\
4.0\end{array}$ \\
\hline Mean & $\begin{array}{c}3.4 \\
(p<0.005)\end{array}$ & $4 \cdot 2$ & 105 & $\begin{array}{c}1 \cdot 2 \\
(p<0 \cdot 02)\end{array}$ & 105 & $2 \cdot 9$ \\
\hline \multicolumn{7}{|c|}{ Burnt patient in recovery phase } \\
\hline 13 & $12 \cdot 6$ & $12 \cdot 1$ & 303 & 3 & 82 & $7 \cdot 6$ \\
\hline
\end{tabular}

All samples from each subject were assayed in the same assay batch to exclude the effect of interassay variation. The blood samples from the control subjects and the weekly samples from the patients were assayed for serum concentrations of testosterone (intra-assay coefficient of variation $7 \%)$, follicle stimulating hormone $(6 \%)$, luteinising hormone $(5 \%)$, and prolactin (5\%) and for sex hormone binding globulin capacity (7\%). Serial samples taken during the studies of pulsatility of luteinising hormone were assayed for only luteinising hormone.

The biological potency of luteinising hormone was determined with mouse Leydig cell preparations in paired samples from eight burnt men. ${ }^{14}$ All eight men had low testosterone concentrations at the time that the first sample was obtained, but the concentrations had returned towards normal at the time of the second sample. The results were expressed as the ratio of luteinising hormone concentration determined by bioassay to that determined by radioimmunoassay and were compared with those in 10 healthy age matched men with normal serum testosterone concentrations. The bioassay had an intra-assay coefficient of variation of $8 \%$.

Concentrations of testosterone, follicle stimulating hormone, luteinising hormone, and prolactin were measured by standard radioimmunoassays. hour sampling period. The pulse amplitude was calculated by subtracting the value at the preceding nadir from the mean of the two consecutive values of luteinising hormone constituting the peak. Statistical analyses were performed with the Wilcoxon rank test for paired or unpaired data as appropriate.

\section{Results}

Serum testosterone concentrations were low in the patients after admission (week 1) compared with the controls and remained low during the study, reaching a nadir of $4 \cdot 1(1 \cdot 4) \mathrm{nmol} / 1$ in week 3 (table I). Twelve patients had a serum testosterone concentration in the range for women $(<2 \mathrm{nmol} / \mathrm{l})$ on at least one occasion after injury. Sex hormone binding globulin capacity was low on admission but increased to concentrations higher than control values by week 4 . Derived concentrations of free testosterone showed a similar trend to concentrations of total testosterone. Concentrations of follicle stimulating hormone did not differ significantly 
from those in the controls on admission but were significantly depressed by week 2. Concentrations of luteinising hormone were similar to control values and showed no significant trend during the study. Prolactin concentrations on admission were not significantly different from those in controls and showed a tendency to increase, but this was not significant.

Figure 1 shows the data from the human chorionic gonadotrophin stimulation tests. Secretion of testosterone from the testes was regarded as normal if it doubled and reached the normal range on day $5 .{ }^{18}$ Five patients showed a normal response; one patient showed no response whatsoever. Figure 2 shows the results of stimulation with luteinising hormone releasing hormone. All six patients showed a normal response of luteinising hormone, but the response of follicle stimulating hormone was reduced in three patients.

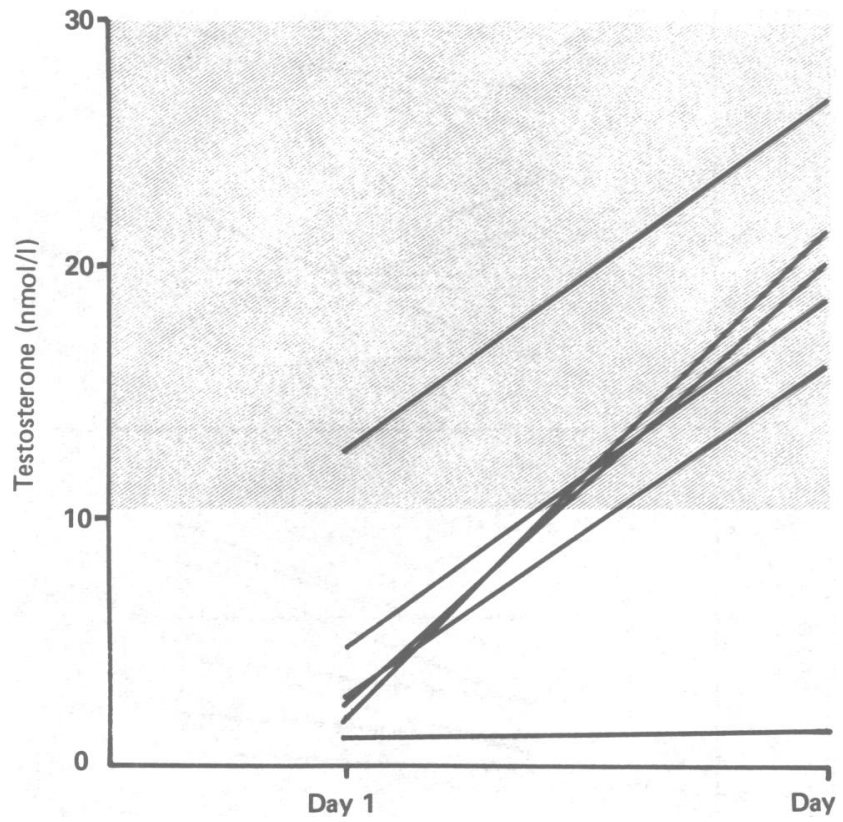

FIG 1-Response of serum testosterone concentration to stimulation with human chorionic gonadotrophin in six burnt men. Shaded area represents range of concentrations in controls.

Table II shows an analysis of the pulsatility of luteinising hormone. The six patients with low serum testosterone concentrations had significantly fewer pulses than the controls $(p<0.02)$, although their mean luteinising hormone concentration and the area under the curve were similar to those in the controls; when pulses occurred they were similar to those in the controls. The patient whose serum testosterone concentration had already returned to normal values had a normal frequency of pulses, but they were of a greater amplitude than those in the controls. Figure 3 shows a series of pulses in a control subject, a patient with a low testosterone concentration, and the patient whose testosterone concentration was normal.

Figure 4 shows data on the bioactivity of luteinising hormone in eight patients. The serum testosterone concentrations in these patients increased significantly from $2 \cdot 4(1 \cdot 0) \mathrm{nmol} / \mathrm{l}$ to $15.6(2 \cdot 1) \mathrm{nmol} / 1$ by recovery $(\mathrm{p}<0.01)$ while the concentration of luteinising hormone as measured by radioimmunoassay did not change significantly $(6.2(1 \cdot 3)$ v $6.4(1 \cdot 3) \mathrm{U} / \mathrm{l})$. The biological activity of luteinising hormone expressed as a ratio in the burnt patients when they had low testosterone concentrations was significantly lower than that in eight control subjects $(3.2(0.6) v 4.4(0.5), \mathrm{p}<0.005)$ or, indeed, that in the same patients after recovery $(4 \cdot 2(1 \cdot 0), \mathrm{p}<0 \cdot 02)$. Seven of the burnt patients showed an increase in the ratio of biological activity as the testosterone concentration rose, but the remaining patient showed no change.

\section{Discussion}

We have confirmed the finding of low serum testosterone concentrations after burns injury. A low sex hormone binding globulin capacity was also found after admission, but this was short lived and values increased to above control values three weeks after admission. Derived free testosterone concentrations showed a similar pattern to total testosterone concentrations. The changes in testosterone concentrations could not be explained by changes in the absolute concentration of luteinising hormone, changes in sex hormone binding globulin capacity, or hyperprolactinaemia.

Five of the six patients tested with human chorionic gonadotrophin showed brisk responses, which suggests that the testes were able to react normally to appropriate stimuli. Dolecek et al found that some patients with particularly severe burns failed to respond to human chorionic gonadotrophin. ${ }^{3}$ The complete absence of a response in one of our patients is difficult to explain as he did not have exceptionally severe burns (14\%).

The response of luteinising hormone to luteinising hormone releasing hormone was normal, which suggests that there was a satisfactory secretory reserve of luteinising hormone. Concentrations of follicle stimulating hormone were definitely depressed after injury, and three patients showed subnormal responses of follicle stimulating hormone to luteinising hormone releasing hormone.
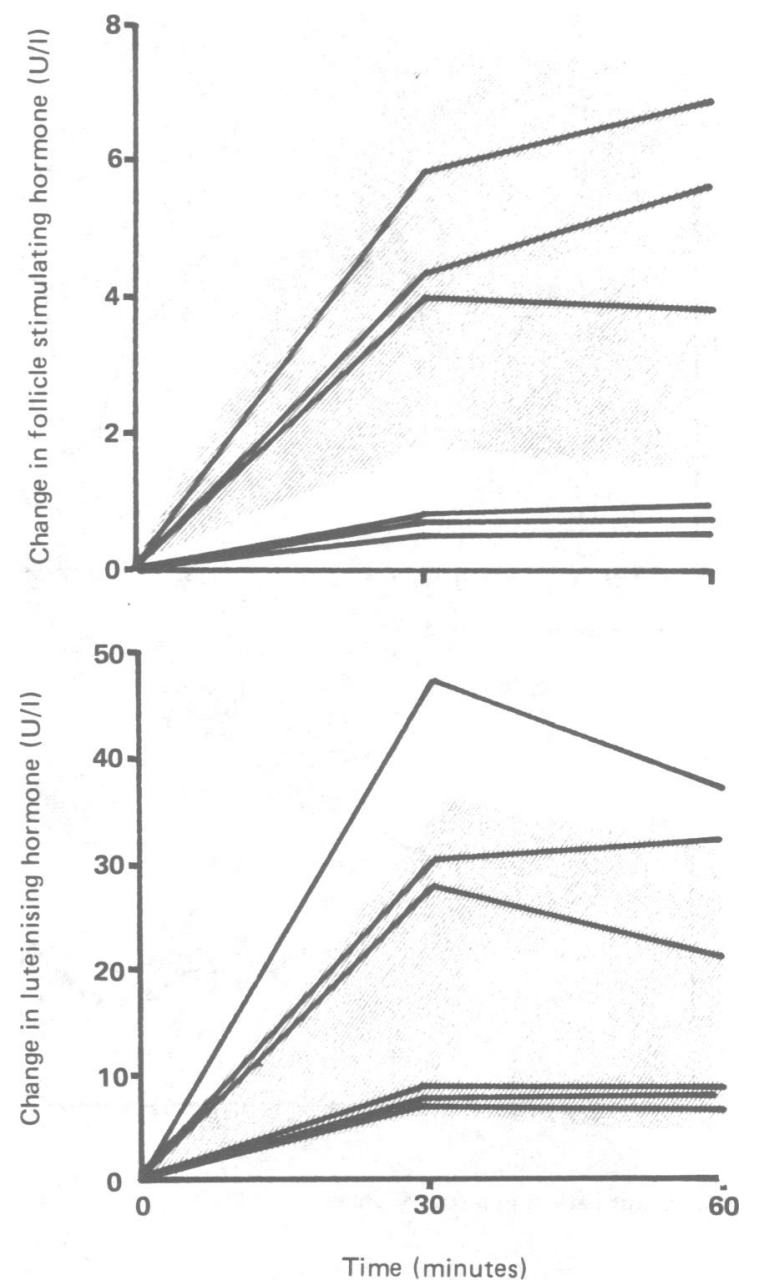

FIG 2-Changes in serum concentrations of follicle stimulating hormone and luteinising hormone from basal values in response to intravenous injection of luteinising hormone releasing hormone in six burnt men. Shaded area represents range of responses in 10 healthy men matched for age.

This finding may be relevant to the disruption of the germinal epithelium described by Dolecek et al in postmortem specimens of severely burnt men. ${ }^{19}$ In vitro studies with cultured porcine Leydig cells have suggested that follicle stimulating hormone might enhance the action of luteinising hormone on testicular steroidogenesis by stimulating Sertoli cells to secrete proteins that increase the activity of Leydig cells. ${ }^{20}$ Thus the low concentrations of follicle stimulating hormone found in burnt men may also contribute to the inhibition of secretion of testosterone. 
Studies on pulses of luteinising hormone in illness are few. Warren et al failed to observe any variation in concentrations of luteinising hormone in serial samples from two ill, postmenopausal women. ${ }^{21}$ Reduced pulsatility of luteinising hormone has been described in conditions such as hyperprolactinaemia ${ }^{22}$ and amenorrhoea related to weight loss. ${ }^{23}$ Loss of pulsatility has been described in patients with chronic renal failure ${ }^{24}$ and chronic liver disease $^{25}$; neither of these conditions is typical of the hypogonadism of illness because a degree of primary testicular failure is often present $^{12}$ and both organs have a role in the metabolism of sex hormones. ${ }^{126}$

We believe that the reduced pulsatility of luteinising hormone in burnt patients may be due to inhibition of the pulsatile release of luteinising hormone releasing hormone as a consequence of the illness. There are, however, alternative explanations. Three patients were receiving low doses of codeine phosphate orally. We know of no evidence to suggest that the low doses of codeine used in this study might exert an adverse effect on hypothalamic-pituitary-
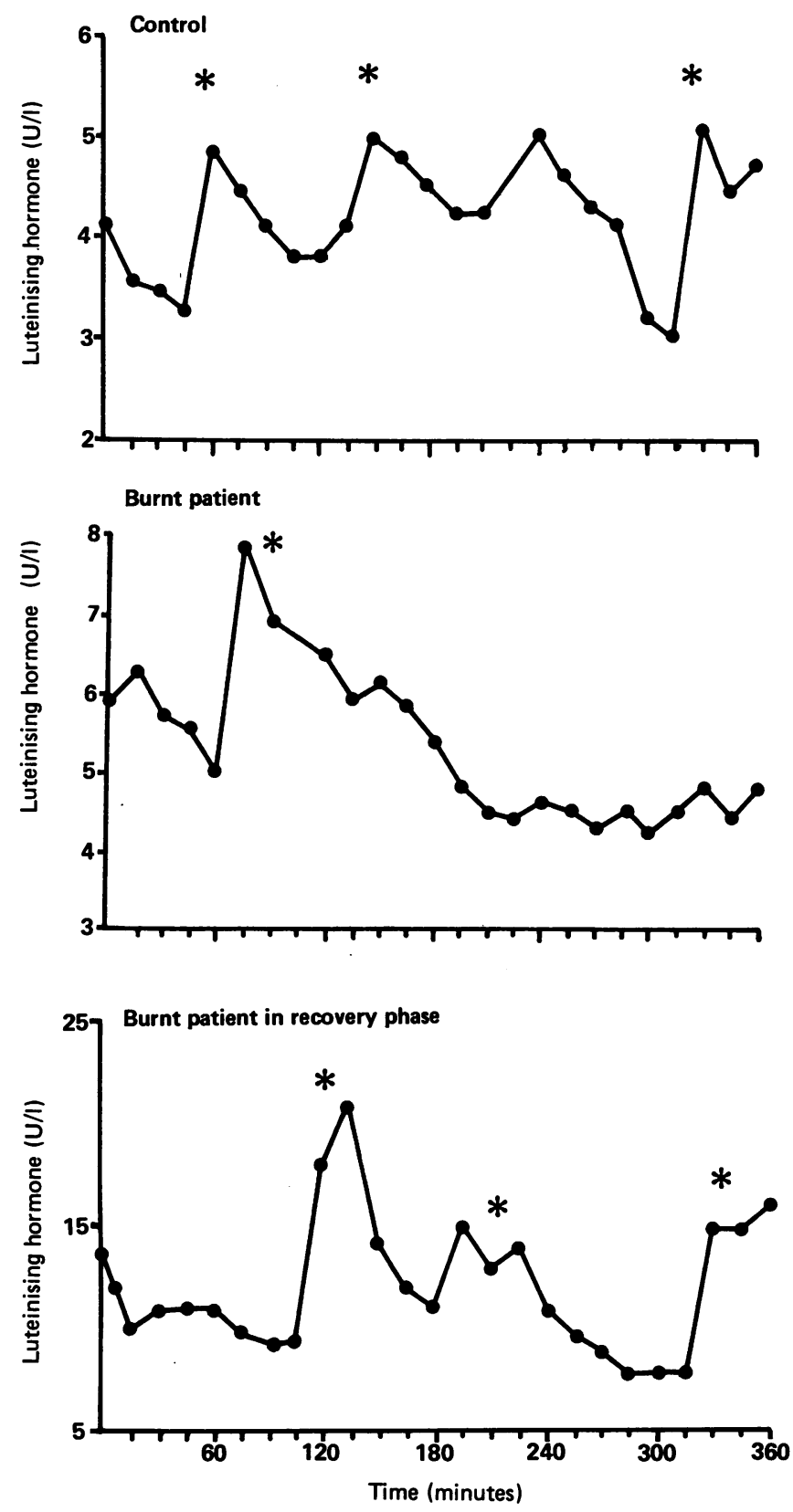

FIG 3-Profile of pulses of luteinising hormone in a control, a burnt patient with a low serum testosterone concentration $(2 \mathrm{nmol} / \mathrm{l})$, and a burnt patient whose serum testosterone concentration had returned to within the normal range. Asterisks indicate pulses.
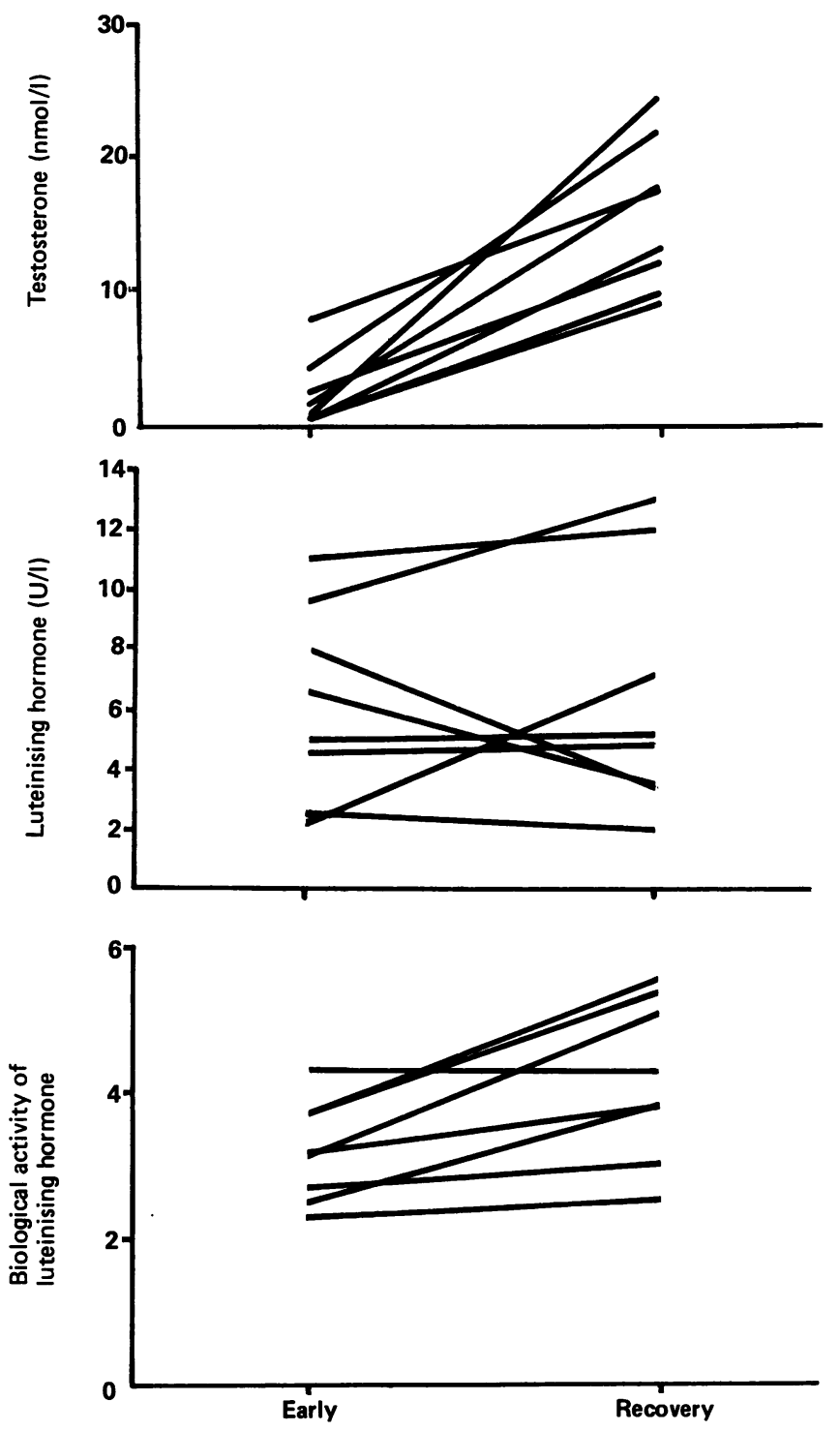

FIG 4-Serum concentrauons of testosterone and luteinising hormone (measured by radioimmunoassay) and biological activity of luteinising hormone (expressed as ratio of concentration measured by bioassay to that measured by radioimmunoassay) in eight burnt men during early and late weeks after injury.

testicular function, but we cannot exclude this possibility. Opiate abuse may lead to low testosterone concentrations, ${ }^{27}$ and healthy men infused intravenously with opiate antagonists show an increased frequency of luteinising hormone pulses, which suggests that endogenous opioid tone may suppress the pulsatility of luteinising hormone. ${ }^{28}$ Detection of pulses of luteinising hormone increases as the sampling interval is shortened. ${ }^{29}$ More frequent blood sampling might have shown a higher frequency of pulses, but this would apply to both the burnt patients and the control subjects. We chose a sampling interval of 15 minutes because we were reluctant to subject our patients to the additional blood loss of more frequent sampling.

The biological activity of luteinising hormone is not constantfor example, the ratio of concentrations determined by bioassay and radioimmunoassay is higher during a peak of luteinising hormone than a nadir ${ }^{13}$ and values fall with age. ${ }^{30}$ The lower biological activity in the random samples of luteinising hormone from our patients may only reflect the reduced pulsatility of luteinising hormone. It is, however, tempting to suggest that secretion of less biologically active luteinising hormone in a constant rather than a pulsatile manner may contribute to the hypogonadism after burns injury and possibly in other conditions.

We thank the laboratory staff of the Department of Biochemistry, 
Glasgow Royal Infirmary, who performed the radioimmunoassays, and the nursing staff of the Burns Unit, Glasgow Royal Infirmary, for their cooperation.

\section{References}

1 Holdsworth S, Atkins RC, De Kretser DM. The pituitary-testicular axis in men with chronic renal failure. $N$ Engl f Med 1977;296:1245-9.

2 Baker HWG, Burger HG, De Kretser DM, et al. A study of the endocrine manifestations of hepatic cirrhosis. Qf Med 1976;45:145-78.

3 Dolecek R, Adamkova M, Sotornikova T, Slosarcik K, Zavada M. Syndrome of afterburn peripheral gland involvement-very low plasma testosterone levels in burned male patients. Acta Chir Plast 1979;21:114-9.

4 Balogh D, Moncayo R, Bauer M. Hormonal dysregulation in severe burns. Burns Incl Therm Inj 1984;10:257-63.

5 Vogel AV, Peake GT, Rada RT. Pituitary-testicular dysfunction in burned men. 7 Clin Endocrinol Metab 1985;60:658-65.

6 Semple Pd'A, Beastall GH, Watson WS, Hume R. Serum testosterone depression associated with hypoxia in respiratory failure. Clin Sci 1980;58:105-6.

7 Nakashima A, Koshiyama K, Uozumi T, et al. Effect of general anaesthesia and surgical stress on serum LH and testosterone in males. Acta Endocrinol (Copenh) 1975;78:258-69.

8 Wang C, Chan V, Tse TF, Yeung RTT. Effect of acute myocardial infarction on pituitarytesticular function. Clin Endocrinol (Oxf) 1978;9:249-53.

9 Rudman D, Fleischer AS, Kutner MH, Raggio JF. Suprahypophyseal hypgonadism and hypothyroidism during prolonged coma after head injury. I Clin Endocrinol Metab 1977;45: $747-54$

10 Quint AR, Kaiser FE. Gonadotrophin determinations and thyrotrophin-releasing hormone and luteinising hormone-releasing hormone testing in critically ill postmenopausal women with hypothyroxinemia. 7 Clin Endocrinol Metab 1985;60:464-71.

11 Woolf PD, Hamill RW, McDonald JV, Lee LA, Kelly M. Transient hypogonadotrophic hypogonadism caused by critical illness. I Clin Endocrinol Metab 1985;60:444-50.

12 Nankin HR, Troen P. Repetitive luteinizing hormone elevations in serum of normal men. $\mathcal{J} \mathrm{Clin}$ Endocrinol Metab 1971;33:558-60.

13 Dufau ML, Veldhuis JD, Fraioli F, Johnson ML, Beitins IZ. Mode of secretion of bioactive luteinizing hormone in man. 7 Clin Endocrinol Metab 1983;57:993-1000.

14 Van Damme MP, Robertson DM, Diczfalusy E. An improved in vitro bioassay method for measuring luteinising hormone ( $\mathrm{LH})$ activity using mouse Leydig cell preparations. Acta Endocrinol (Copenh) 1974;77:655-71.
15 Rosner W. A simplified method for the quantitative determination of testosterone-estradiolbinding globulin activity in human plasma. 7 Clin Endocrinol Metab 1972;34:983-8.

16 Anderson DC, Thorner MO, Fisher RA, Woodham JP, Goble HL, Besser GM. Effects of hormonal treatment on plasma unbound androgen levels in hirsute women. Acta Endocrinol [Suppl] (Copenh) 1975;199:224.

17 Santen RJ, Bardin CW. Episodic luteinizing hormone secretion in man. Pulse analysis, clinical interpretation, physiological mechanisms. F Clin Invest 1973;52:2617-28.

18 Anderson DC, Marshall JC, Young JL, Fraser TR. Stimulation tests of pituitary-Leydig cell function in normal male subjects and hypogonadal men. Clin Endocrinol (Oxf) 1972;1:127-40.

19 Dolecek R, Dvoracek C, Jezek M, Kubis M, Sajnar J, Zavada M. Very low serum testosterone levels and severe impairment of spermatogenesis in burned male patients. Correlation with basal levels of FSH, LH and PRL after LHRH+TRH. Endocrinol Exp (Bratisl) 1983;17:33-45.

20 Benahmed M, Grenot C, Tabone E, Sanchez P, Morera AM. FSH regulates cultured Leydig cell unction via Sertoli cell proteins: an in vitro study. Biochem Biophys Res Commun 1985;132: 729-34.

21 Warren MP, Siris ES, Petrovich C. The influence of severe illness on gonadotrophin secretion in the postmenopausal female. $\mathcal{I}$ Clin Endocrinol Metab 1977;45:99-104.

22 Winters SJ, Troen P. Altered pulsatile secretion of luteinizing hormone in hypogonadal men with hyperprolactinaemia. Clin Endocrinol $(O x f)$ 1984;21:257-63.

23 Reame NE, Saunders SE, Case GD, Kelch RP, Marshall JC. Pulsatile gonadotrophin secretion in women with hypothalamic amenorrhea: evidence that reduced frequency of gonadotropinreleasing hormone secretion is the mechanism of persistent anovulation. $f$ Clin Endocrinol Metab 1985;61:851-8.

24 Rodger RSC, Morrison L, Dewar JH, Wilkinson R, Ward MK, Kerr DNS. Loss of pulsatile luteinising hormone secretion in men with chronic renal failure. $\mathrm{Br}$ Med $\mathcal{J}$ 1985;291:1598-600.

25 Bannister P, Handley T, Chapman C, Losowsky MS. Hypogonadism in chronic liver disease: impaired release of luteinising hormone. Br Med f 1986;293:1191-3.

26 Gordon GG, Olivo J, Rafii F, et al. Conversion of androgens to estrogen in cirrhosis of the liver. f Clin Endocrinol Metab 1975;40:1018-26.

27 Mendelson JH, Mello NK. Plasma testosterone levels during chronic heroin use and protracted abstinence. Clin Pharmacol Ther 1975;17:529-33.

28 Grossman A, Moult PJA, Gaillard RC, et al. The opioid control of LH and FSH release: effects of met-enkephalin analogue and naloxone. Clin Endocrinol (Oxf) 1981;14:41-7.

29 Crowley WF, Filicori M, Spratt DI, Santoro NF. The physiology of gonadotrophin-releasing hormone (GnRH) secretion in men and women. Recent Prog Horm Res 1985;41:473-531.

30 Warner BA, Dufau ML, Santen RJ. Effects of ageing and illness on the pituitary testicular axis in men: qualitative as well as quantitative changes in luteinizing hormone. $f$ Clin Endocrinol Metab 1985;60:263-8.

(Accepted 26 May 1987)

\title{
Chorionic villi sampling: cytogenetic and clinical findings in $\mathbf{5 0 0}$ pregnancies
}

\author{
NICO J LESCHOT, HANS WOLF, MARIANNE VERJAAL, LIA C VAN PROOIJEN-KNEGT, \\ ELLEN G DE BOER, HUMPHREY H H KANHAI, GODELIEVE C M L CHRISTIAENS
}

\section{Abstract}

The cytogenetic findings were analysed in a series of 500 pregnancies in which chorionic villi sampling was performed. In all cases a direct method was used, karyotyping being successful in 481 cases $(96 \cdot 2 \%)$. The main indication for sampling was

Department of Human Genetics, University of Amsterdam, Academic Medical Centre, Meibergdreef 15, 1105 AZ Amsterdam, The Netherlands NICO J LESCHOT, MD, clinical geneticist

MARIANNE VERJAAL, MD, clinical geneticist

LIA C VAN PROOIJEN-KNEGT, PHD, clinical cytogeneticist

ELLEN G DE BOER, technician

University Department of Obstetrics and Gynaecology, Academic Medical

Centre, Meibergdreef 9, 1105 AZ Amsterdam, The Netherlands

HANS WOLF, MB, gynaecologist

University Department of Obstetrics and Gynaecology, Academic Hospital, Rijnsburgerweg 10, 2333 AA Leiden, The Netherlands

HUMPHREY H H KANHAI, MD, gynaecologist

University Department of Obstetrics and Gynaecology, Academic Hospital,

Catharijnesingel 101, 3511 GV Utrecht, The Netherlands

GODELIEVE C M L CHRISTIAENS, MD, gynaecologist

Correspondence to: Dr Leschot. maternal age over 36 (412 cases; 82.4\%). Abnormal laboratory findings resulted in 24 terminations of pregnancy $(4.8 \%)$; in addition five unexpected balanced chromosome rearrangements were detected. Twelve of 15 cytogenetic discrepancies were detected at amniocentesis, two after termination, and one at spontaneous abortion. Complete follow up data were available for the first 250 patients, among whom nine pregnancies (3.6\%) ended in spontaneous abortion before the 20th week. There were no false negative findings. Seventy additional chromosome studies were performed because of failure of chorionic villi sampling or equivocal results, or for confirmation.

Counselling before chorionic villi sampling should include the possibility that subsequent amniocentesis may be needed should mosaicism or other unexpected abnormalities be found. The success rate and accuracy of karyotyping chorionic villi samples by the direct method are acceptable but distinctly less than those of karyotyping cultured amniotic fluid cells.

\section{Introduction}

Simoni et al initially described chorionic villi sampling in the prenatal diagnosis of fetal chromosome abnormalities, ${ }^{1}$ and their report was followed by two collaborative studies ( $M$ Mikkelsen and $S$ Ayme, unpublished $)^{2}$ and only a few large one centre studies. ${ }^{3+}$ We began chorionic villi sampling for prenatal chromosome studies 